\title{
openheart Atrioesophageal fistula following ablation procedures for atrial fibrillation: systematic review of case reports
}

\author{
Patricia Chavez, ${ }^{1}$ Franz H Messerli, ${ }^{1}$ Abel Casso Dominguez, ${ }^{1}$ Emad F Aziz, ${ }^{1}$ \\ Tina Sichrovsky, ${ }^{1}$ Daniel Garcia, ${ }^{2}$ Connor D Barrett, ${ }^{1}$ Stephan Danik ${ }^{1}$
}

To cite: Chavez $\mathrm{P}$ Messerli FH, Casso Dominguez $A$, et al. Atrioesophageal fistula following ablation procedures for atrial fibrillation: systematic review of case reports. Open Heart 2015;2: 000257. doi:10.1136/openhrt-2015000257

Received 1 March 2015 Revised 12 May 2015 Accepted 2 June 2015

\section{CrossMark}

\footnotetext{
${ }^{1}$ Division of Cardiology, St Luke's-Roosevelt Hospital Center, Mount Sinai Healthcare System, New York, New York, USA ${ }^{2}$ University of Miami Hospital, University of Miami, Miami, Florida, USA
}

Correspondence to Dr Patricia Chavez; Pchavez@chpnet.org

\section{ABSTRACT \\ Background: Atrioesophageal fistula (AEF) is a rare but serious adverse event of atrial fibrillation (AF) ablation. \\ Objective: To identify the clinical characteristics of AEF following ablation procedures for $\mathrm{AF}$ and determine the associated mortality. \\ Methods: A systematic review of observational cases of AEF following ablation procedures for AF was performed following the Preferred Reporting Items for Systematic Reviews and Meta-Analyses (PRISMA) statement protocol.}

Results: 53 cases were identified. Mean age was 54 \pm 13 years; $73 \%$ (39/53) of cases occurred in males. Mean interval between procedure and presentation was $20 \pm 12$ days, ranging from 2 to 60 days. AEF was observed in 12 patients who underwent surgical radiofrequency ablation (RFA) and in 41 patients with percutaneous RFA. Fever was the most common presenting symptom $(n=44)$ followed by neurological deficits $(n=27)$ and haematemesis $(n=19)$. CT of the chest $(n=27)$ was the preferred diagnostic test. Patients who did not receive a primary esophageal repair were more likely to have a deadly outcome (34\% vs $83 \%$; $\mathrm{p}<0.05)$. No difference in mortality rate was found between patients who underwent surgical RFA when compared with percutaneous RFA ( $58 \%$ vs $56 \%$; $p=0.579$ ). No association was found between onset of symptoms and mortality ( $19 \pm 10$ vs $23 \pm 14$ days; $p=0.355)$.

Conclusions: AEF following ablation procedures for $A F$ is a serious complication with high mortality rates. Presenting symptoms most often include a triad of fever, neurological deficit and/or haematemesis within 60 days of procedure. The preferred diagnostic test is CT of the chest. The treatments of choice is surgical repair.

\section{INTRODUCTION}

Catheter ablation for atrial fibrillation (AF) is becoming a mainstream treatment particularly in patients with paroxysmal AF with severe symptomatology. ${ }^{1}$ As the number of

\section{KEY QUESTIONS}

What is already known about this subject?

- Ablation for atrial fibrillation is becoming a mainstream treatment in cases resistant to conventional therapy or with severe symptomatology. As the number of procedures continues to rise, reports of one of the most devastating complications, atrioesophageal fistula, have also increased.

What does this study add?

- This is a review of case reports describing the signs and symptoms, diagnosis, management, and the associated mortality of this important complication of ablation procedures for atrial fibrillation. This is the largest review of case reports to date, including 53 cases in 37 peerreviewed publications.

How might this impact on clinical practice?

- We considered it critical to review the clinical findings, diagnostic methods and therapeutic option available for this condition. The early recognition and prompt management might change its serious outcome and high mortality.

procedures continues to rise, reports of one of the most devastating complications, atrioesophageal fistula (AEF), have also increased. In 2001, Mohr et al, ${ }^{2}$ reporting outcomes after intraoperative radiofrequency ablation (RFA) of $\mathrm{AF}$ in 234 patients at the 81st Annual Meeting of The American Association for Thoracic Surgery, described three patients who developed AEF, one of whom had a fatal outcome.

Since this initial observation, at least 53 cases of AEF following AF ablation procedures have been reported. Although differences in pathogenesis of each case have been reported, the similarities in the clinical presentations allow one to characterise this rare entity. Given its serious outcome and 
high mortality, we considered it critical to review the clinical findings, diagnostic methods, and therapeutic options available for this condition.

\section{METHODS}

\section{Search strategy}

The objective of this review was to identify the case reports on AEF following ablation procedures for AF. A systematic search of the database PubMed from inception to December 2014 was performed. The search terms included atrioesophageal fistula OR atrio-esophageal fistula OR atrio-oesophageal fistula OR esophagoatrial fistula OR oesophago-atrial fistula. This terms were searched as free text in the title or the abstract.

We limited our search to case reports of humans without timeframe limit. No language restriction was applied. The reference lists of bibliographies of the identified articles were also reviewed.

\section{Selection criteria}

To be included in the analysis, a case report had to fulfil the following criteria: (1) report $\mathrm{AF}$ as the primary diagnosis for ablation procedure; (2) report clinical presentation; (3) report diagnostic modality used; (4) report management applied and (5) report outcome. Exclusion criteria involved the following: unknown aetiology of AEF and pericardioesophageal fistulas.

\section{Data extraction}

The case reports were identified and data extracted using standardised protocol. Disagreements were resolved by arbitration (PC and FHM), and consensus was reached after discussion. We extracted data such as baseline patient demographics, clinical presentation, diagnostic modalities and therapeutic management and outcome.

\section{Statistical analysis}

For this systematic review of case reports, we used the Preferred Reporting Items for Systematic Reviews and Meta-Analyses (PRISMA) statement protocol. ${ }^{3}$ Continuous data are presented as means with SD. Absolute numbers and percentages are presented for categorical data. Comparison between categorical variables was evaluated by using the Fisher exact test (IBM SPSS Statistics V.13 for Windows). Statistical significance was set at 0.05 .

\section{RESULTS}

\section{Demographics and clinical presentation}

Fifty-three cases were identified (table 1). Mean age was $54 \pm 13$ years; $73 \%(39 / 53)$ of cases occurred in males. Mean interval between procedure and presentation was $20 \pm 12$ days, ranging from 2 to 60 days.

AEF was noticed in 12 patients who underwent surgical RFA and in 41 patients who underwent percutaneous RFA. One case was reported after cryoballoon ablation. ${ }^{29}$ Fever was the most common presenting symptom
( $n=44)$ followed by neurological deficits ( $n=27$; including motor and language impairment), haematemesis $(n=19)$, altered mental status $(n=15)$, chest pain $(n=11)$ and seizures $(\mathrm{n}=7$; figure 1$)$.

\section{Diagnostic evaluation, treatment and outcome}

CT of the chest $(n=27)$ and head $(n=15)$ were the preferred diagnostic modalities (figure 2), with multifocal infarcts consistent with air embolism $(n=13)$ and pneumomediastinum $(\mathrm{n}=12)$ being the most common findings.

Among the CT of the chest findings pneumomediastinum was a strong indicator of esophageal injury, as well as hemopericardium and pneumopericardium. ${ }^{5} 101431$ At least two cases reported pneumopericardium and four cases reported intracardiac air. Transthoracic echocardiography was performed in 11 cases and transesophageal echocardiography (TEE) in three cases.

No difference in mortality rate was found between patients who underwent surgical RFA when compared with percutaneous RFA (10/29, 58\% vs 20/24, 56\%; $\mathrm{p}=0.579$ ). Patients who did not receive a primary esophageal repair were more likely to have a deadly outcome (34\% with surgical treatment vs $83 \%$ with conservative treatment; $\mathrm{p}<0.05)$. In those cases that underwent corrective surgical intervention, the left atrium (LA) was identified, exposing the fistula between the atrium and esophagus. ${ }^{5}$ No association was found between onset of symptoms and mortality ( $19 \pm 10$ vs $23 \pm 14$ days; $\mathrm{p}=0.355$ ).

\section{DISCUSSION}

AEF can be defined as an abnormal communication between the atrium and the esophagus as a result of a trauma, although idiopathic fistulas have been described. ${ }^{41}$ Literature reports a $15 \%$ rise in the rates of $\mathrm{AF}$ ablations resulting in an increase from $0.06 \%$ to $0.79 \%$ over 15 years (1990-2005 period), which is parallel to a rise in the prevalence of $\mathrm{AF}$ itself-from 270000 to over 2.2 million people affected-a number that continues to grow. ${ }^{42}$ The incidence of AEF varies from $0.03 \%$ to $1.5 \%$; however, its true incidence may be under-reported. ${ }^{53-45}$

Prior reports have evaluated this topic. Finsterer $e t a l^{46}$ and Stöllberger $e t a t^{47}$ focused on the neurological manifestations of AEF after RFA. Nair et at ${ }^{48}$ performed a review of the epidemiology, clinical features, aetiopathogenesis and management of AEF after RFA. Singh et a $t^{49}$ reported a review of the principles of AEF repair and clinical outcomes in 29 patients. We describe the largest case report review to date, evaluating 53 cases of AEF after RFA in 37 peer-reviewed publications.

\section{Demographics and clinical presentation}

AEF has been reported to be more prevalent in males than females. ${ }^{50}$ We found similar results, with $73 \%$ of the cases occurring in males. This could partially be 


\begin{tabular}{|c|c|c|c|c|c|c|c|c|c|c|c|}
\hline Author & $\begin{array}{l}\text { Number } \\
\text { of cases }\end{array}$ & Gender & $\begin{array}{l}\text { Age } \\
\text { (years) }\end{array}$ & Procedure & $\begin{array}{l}\text { Post } \\
\text { procedure } \\
\text { day }\end{array}$ & Clinical presentation & Imaging & Findings & $\begin{array}{l}\text { Diagnostic } \\
\text { procedure }\end{array}$ & Treatment & Outcome \\
\hline $\begin{array}{l}\text { Sonmez } \\
\text { et }\left.a\right|^{4}\end{array}$ & 1 & Female & 58 & $\begin{array}{l}\text { Surgical: LRFA } \\
\text { - melo } \\
\text { technique }\end{array}$ & 22 & $\begin{array}{l}\text { Fever, shivers, } \\
\text { numbness right arm }\end{array}$ & TTE & LA thrombus & EGD & $\begin{array}{l}\text { Thrombectomy, } \\
\text { pericardial } \\
\text { sutures }\end{array}$ & Death \\
\hline Doll et $a^{\Gamma}$ & 1 & Male & 42 & Surgical: IRAAF & 10 & Fever, postprandial TIA & TTE & Normal & $\begin{array}{l}\text { Exploratory } \\
\text { thoracotomy }\end{array}$ & Surgical & Survived \\
\hline Doll et $a^{p}$ & 1 & Female & 62 & Surgical: IRAAF & 6 & Haematemesis & EGD & NA & Pathology & None & Death \\
\hline Doll et $a^{\Gamma}$ & 1 & Male & 59 & Surgical: IRAAF & 12 & $\begin{array}{l}\text { Fever, neurological } \\
\text { symptoms }\end{array}$ & $\begin{array}{l}\text { CT of the } \\
\text { chest }\end{array}$ & $\begin{array}{l}\text { Contrast and free air in } \\
\text { the mediastinum }\end{array}$ & $\begin{array}{l}\text { Exploratory } \\
\text { Thoracotomy }\end{array}$ & Surgical & Survived \\
\hline Doll et ap & 1 & Male & 36 & Surgical: IRAAF & 11 & Chest pain & $\begin{array}{l}\text { CT of the } \\
\text { chest }\end{array}$ & $\begin{array}{l}\text { Oesophageal } \\
\text { perforation }\end{array}$ & $\begin{array}{l}\text { Exploratory } \\
\text { thoracotomy }\end{array}$ & Surgical & Survived \\
\hline $\begin{array}{l}\text { Pappone } \\
\text { et } a^{f}\end{array}$ & 1 & Male & 36 & $\begin{array}{l}\text { Percutaneous: } \\
\text { CPVA }\end{array}$ & 3 & $\begin{array}{l}\text { Fever, pleuritic chest } \\
\text { pain, seizures }\end{array}$ & CT of the head & Bilateral ischaemia & $\begin{array}{l}\text { CT of the } \\
\text { chest }\end{array}$ & Surgical & Survived \\
\hline $\begin{array}{l}\text { Pappone } \\
\text { et } a^{f}\end{array}$ & 1 & Male & 21 & $\begin{array}{l}\text { Percutaneous: } \\
\text { CPVA }\end{array}$ & 1 & $\begin{array}{l}\text { Fever, grand mal } \\
\text { seizure }\end{array}$ & CT of the head & Unremarkable & TEE & Non-surgical & Death \\
\hline $\begin{array}{l}\text { Scanavacca } \\
\text { et } a l^{7}\end{array}$ & 1 & Male & 72 & $\begin{array}{l}\text { Percutaneous: } \\
\text { RFA }\end{array}$ & 22 & $\begin{array}{l}\text { Seizures, } \\
\text { haematemesis }\end{array}$ & NA & NA & EGD & None & Death \\
\hline $\begin{array}{l}\text { Zirlik and } \\
\text { Nordt }^{8}\end{array}$ & 1 & Male & 66 & $\begin{array}{l}\text { Surgical: MVR } \\
\text { and Maze } \\
\text { procedure }\end{array}$ & 14 & Collapse & CT of the head & $\begin{array}{l}\text { Multiple intracerebral air } \\
\text { emboli and infarctions }\end{array}$ & EGD & Non-surgical & Death \\
\hline Bunch et $a \rho$ & 1 & Male & 48 & $\begin{array}{l}\text { Percutaneous: } \\
\text { RFA }\end{array}$ & 14 & $\begin{array}{l}\text { Fever, chest pain, } \\
\text { dysphagia }\end{array}$ & $\begin{array}{l}\text { CT of the } \\
\text { chest }\end{array}$ & $\begin{array}{l}3 \mathrm{~mm} \text { oesophageal } \\
\text { perforation at level of } \\
\text { atrium }\end{array}$ & EGD & Non-surgical & Survived \\
\hline $\begin{array}{l}\text { Schley } \\
\text { et } a l^{0}\end{array}$ & 1 & Male & 37 & $\begin{array}{l}\text { Percutaneous: } \\
\text { RFA }\end{array}$ & 25 & $\begin{array}{l}\text { Fever, grand mal } \\
\text { seizure, status } \\
\text { epilepticus }\end{array}$ & CT of the head & Ischaemic lesions & $\begin{array}{l}\text { CT of the } \\
\text { chest }\end{array}$ & Surgical & Survived \\
\hline $\begin{array}{l}\text { Cummings } \\
\text { et } a l^{11}\end{array}$ & 9 & $\begin{array}{l}\text { Male }=4 \\
\text { Female }=5\end{array}$ & NA & $\begin{array}{l}\text { Percutaneous: } \\
\text { PRFA }\end{array}$ & $\begin{array}{l}12.3 \\
(10-16)\end{array}$ & $\begin{array}{l}\text { Sepsis }(n=9) \text {, } \\
\text { neurological symptoms } \\
(n=8) \text {; angina }(n=2) ; G \text { I } \\
\text { bleed }(n=3)\end{array}$ & CT of the head & Intravascular air $(\mathrm{n}=2)$ & $\begin{array}{l}\text { CT of the } \\
\text { chest } 3 / 4 \text {; } \\
\text { autopsy } 6 / 9\end{array}$ & $\begin{array}{l}\text { Surgical=3; } \\
\text { Non-surgical=6 }\end{array}$ & $\begin{array}{l}\text { Death } \\
(n=9)\end{array}$ \\
\hline $\begin{array}{l}\text { Dagres } \\
\text { et } a l^{12}\end{array}$ & 5 & $\begin{array}{l}\text { Male }=4 \\
\text { Female }\end{array}$ & $\begin{array}{l}51 \\
(35- \\
76)\end{array}$ & $\begin{array}{l}\text { Surgical RFA } \\
(n=4) ; \\
\text { Percutaneous } \\
\text { RFA }(n=1)\end{array}$ & $8-28$ & $\begin{array}{l}\text { Fever }(n=3) \text {, chest pain } \\
(n=2) \text {, hemiparesis } \\
(n=3) \text {, grand mal } \\
\text { seizure }(n=1) \text {, aphasia } \\
(n=1)\end{array}$ & NA & NA & $\begin{array}{l}\text { CT of the } \\
\text { chest }\end{array}$ & $\begin{array}{l}\text { Surgery }(n=3) \\
\text { attempted } \\
\text { surgery }(n=2)\end{array}$ & $\begin{array}{l}\text { Death } \\
(n=2)\end{array}$ \\
\hline Preis et $a l^{13}$ & 1 & Male & 56 & $\begin{array}{l}\text { Percutaneous: } \\
\text { PVI with RFA }\end{array}$ & 38 & $\begin{array}{l}\text { Malaise, chills, bilateral } \\
\text { arm weakness }\end{array}$ & TEE & No vegetations & $\begin{array}{l}\text { CT of the } \\
\text { chest }\end{array}$ & Surgical & Survived \\
\hline $\begin{array}{l}\text { D'Avila } \\
\text { et } a 1^{15}\end{array}$ & 1 & Male & 56 & $\begin{array}{l}\text { Percutaneous: } \\
\text { RFA }\end{array}$ & 28 & $\begin{array}{l}\text { Epigastric pain, } \\
\text { dysphagia, tactile fever; } \\
\text { focal weakness, } \\
\text { anomia, acalculia, } \\
\text { agraphia }\end{array}$ & $\begin{array}{l}\text { MRI of the } \\
\text { brain }\end{array}$ & $\begin{array}{l}\text { Multiple subacute } \\
\text { embolic events }\end{array}$ & $\begin{array}{l}\text { CT of the } \\
\text { chest }\end{array}$ & Surgical & Survived \\
\hline
\end{tabular}




\begin{tabular}{|c|c|c|c|c|c|c|c|c|c|c|c|}
\hline Author & $\begin{array}{l}\text { Number } \\
\text { of cases }\end{array}$ & Gender & $\begin{array}{l}\text { Age } \\
\text { (years) }\end{array}$ & Procedure & $\begin{array}{l}\text { Post } \\
\text { procedure } \\
\text { day }\end{array}$ & Clinical presentation & Imaging & Findings & $\begin{array}{l}\text { Diagnostic } \\
\text { procedure }\end{array}$ & Treatment & Outcome \\
\hline $\begin{array}{l}\text { Purerfellner } \\
\text { et } a \text { P }^{8}\end{array}$ & 1 & Male & 49 & $\begin{array}{l}\text { Percutaneous: } \\
\text { RFA }\end{array}$ & 29 & $\begin{array}{l}\text { Fever, chills, nausea, } \\
\text { emesis, altered mental } \\
\text { status, athetotic } \\
\text { movements; skin } \\
\text { changes, } \\
\text { haematemesis }\end{array}$ & EGD & $\begin{array}{l}\text { Unable to localise } \\
\text { source of bleeding }\end{array}$ & EGD & Non-surgical & Death \\
\hline $\begin{array}{l}\text { Stockigt } \\
\text { et } a \text { P }^{9}\end{array}$ & 1 & Male & 78 & $\begin{array}{l}\text { Percutaneous: } \\
\text { cryoballoon PV } \\
\text { isolation }\end{array}$ & 28 & $\begin{array}{l}\text { Fever, shivers, cough } \\
\text { for } 10 \text { days, followed by } \\
\text { neurological symptoms }\end{array}$ & $\begin{array}{l}\text { CT of the } \\
\text { chest and } \\
\text { abdomen }\end{array}$ & Negative & Cardiac CT & Non-surgical & Survived \\
\hline $\begin{array}{l}\text { Tancevski } \\
\text { et } a \beta^{\beta 0}\end{array}$ & 1 & Male & 45 & $\begin{array}{l}\text { Percutaneous: } \\
\text { transcatheter } \\
\text { ablation }\end{array}$ & 42 & $\begin{array}{l}\text { Fever, weakness, } \\
\text { sensory loss of right } \\
\text { limbs }\end{array}$ & $\begin{array}{l}\text { CT of the } \\
\text { chest and } \\
\text { abdomen }\end{array}$ & $\begin{array}{l}\text { CT of the chest: AEF; } \\
\text { CT of the abdomen: } \\
\text { multiple renal and } \\
\text { splenic infarctions }\end{array}$ & CT surgery & Surgical & Survived \\
\hline $\begin{array}{l}\text { Haggerty } \\
\text { et } a \beta^{1}\end{array}$ & 1 & Male & 27 & $\begin{array}{l}\text { Percutaneous: } \\
\text { PV RFA }\end{array}$ & 22 & $\begin{array}{l}\text { Fever, chills, } \\
\text { hypotension, } \\
\text { haematemesis }\end{array}$ & $\begin{array}{l}\text { CT of the } \\
\text { chest }\end{array}$ & $\begin{array}{l}\text { Pneumomediastinum } \\
\text { adjacent to LA }\end{array}$ & CT surgery & Surgical & Survived \\
\hline $\begin{array}{l}\text { Kanth and } \\
\text { Fang }^{32}\end{array}$ & 1 & Female & 69 & $\begin{array}{l}\text { Percutaneous: } \\
\text { RFA }\end{array}$ & 60 & $\begin{array}{l}\text { Sepsis, ischaemic } \\
\text { stroke, melena }\end{array}$ & $\begin{array}{l}\text { CT of the } \\
\text { chest }\end{array}$ & AEF & EGD & Non-surgical & Death \\
\hline $\begin{array}{l}\text { Ben-David } \\
\text { et } a \beta^{33}\end{array}$ & 1 & Female & 73 & $\begin{array}{l}\text { Percutaneous: } \\
\text { RFA }\end{array}$ & 9 & Pneumomediastinum & UGI series & $\begin{array}{l}4 \mathrm{~mm} \text { oesophageal } \\
\text { perforation at } 6 \mathrm{~cm} \text { from } \\
\text { GEJ }\end{array}$ & EGD & Non-surgical & Death \\
\hline $\begin{array}{l}\text { Hartman } \\
\text { et } a \beta^{34}\end{array}$ & 1 & Male & 62 & $\begin{array}{l}\text { Percutaneous: } \\
\text { RFA }\end{array}$ & 30 & $\begin{array}{l}\text { Odynophagia, fever, } \\
\text { chills, rigours, syncope }\end{array}$ & $\begin{array}{l}\text { Cardiac } \\
\text { catheterisation }\end{array}$ & Negative & $\begin{array}{l}\text { CT of the } \\
\text { chest }\end{array}$ & Surgical & Survived \\
\hline Zini et $a \beta^{35}$ & 1 & Male & 44 & $\begin{array}{l}\text { Percutaneous: } \\
\text { RFA }\end{array}$ & - & $\begin{array}{l}\text { Altered mental status, } \\
\text { stupor }\end{array}$ & CT of the head & Multifocal air emboli & EGD & $\begin{array}{l}\text { Antibiotics, } \\
\text { antithrombotics, } \\
\text { fistula repair }\end{array}$ & Death \\
\hline Rivera et $a{ }^{\beta 6}$ & 1 & Female & 50 & $\begin{array}{l}\text { Percutaneous: } \\
\text { RFA }\end{array}$ & 28 & Minor haematemesis & $\begin{array}{l}\text { CT of the } \\
\text { chest }\end{array}$ & $\begin{array}{l}\text { AEF and pleural } \\
\text { effusions }\end{array}$ & EGD & Surgical & Survived \\
\hline $\begin{array}{l}\text { Tan and } \\
\text { Coffey }^{37}\end{array}$ & 1 & Female & 67 & $\begin{array}{l}\text { Surgical: MVR } \\
\text { and Maze } \\
\text { procedure }\end{array}$ & 20 & $\begin{array}{l}\text { Nausea, fever, } \\
\text { numbness left foot; } \\
\text { unresponsiveness }\end{array}$ & CT of the head & $\begin{array}{l}\text { CT of the head: air } \\
\text { embolism RSFA }\end{array}$ & $\begin{array}{l}\text { CT of the } \\
\text { chest }\end{array}$ & Non-surgical & Death \\
\hline Shim et $a{ }^{\beta 8}$ & 1 & Male & 46 & $\begin{array}{l}\text { Percutaneous: } \\
\text { RFA }\end{array}$ & 2 & $\begin{array}{l}\text { Fever, chills, cough, } \\
\text { headache; confusion, } \\
\text { generalised tonic-clonic } \\
\text { seizures }\end{array}$ & TTE/TEE & No thrombus & $\begin{array}{l}\text { CT of the } \\
\text { chest }\end{array}$ & Surgical & Survived \\
\hline $\begin{array}{l}\text { Neven } \\
\text { et } a \beta^{\beta 9}\end{array}$ & 1 & Male & 69 & $\begin{array}{l}\text { Percutaneous: } \\
\text { HIFU }\end{array}$ & 31 & $\begin{array}{l}\text { Fever, haematemesis, } \\
\text { seizures, phrenic nerve } \\
\text { palsy }\end{array}$ & CT of the head & Cerebral embolism & Autopsy & Non-surgical & Death \\
\hline Dixit et $a{ }^{40}$ & 1 & Female & NA & $\begin{array}{l}\text { Percutaneous: } \\
\text { PV isolation }\end{array}$ & 14 & $\begin{array}{l}\text { Fever, haematemesis, } \\
\text { nausea }\end{array}$ & EGD & $\begin{array}{l}\text { Possible Mallory-Weiss } \\
\text { tear }\end{array}$ & $\begin{array}{l}\text { CT of the } \\
\text { head }\end{array}$ & Non-surgical & Death \\
\hline
\end{tabular}




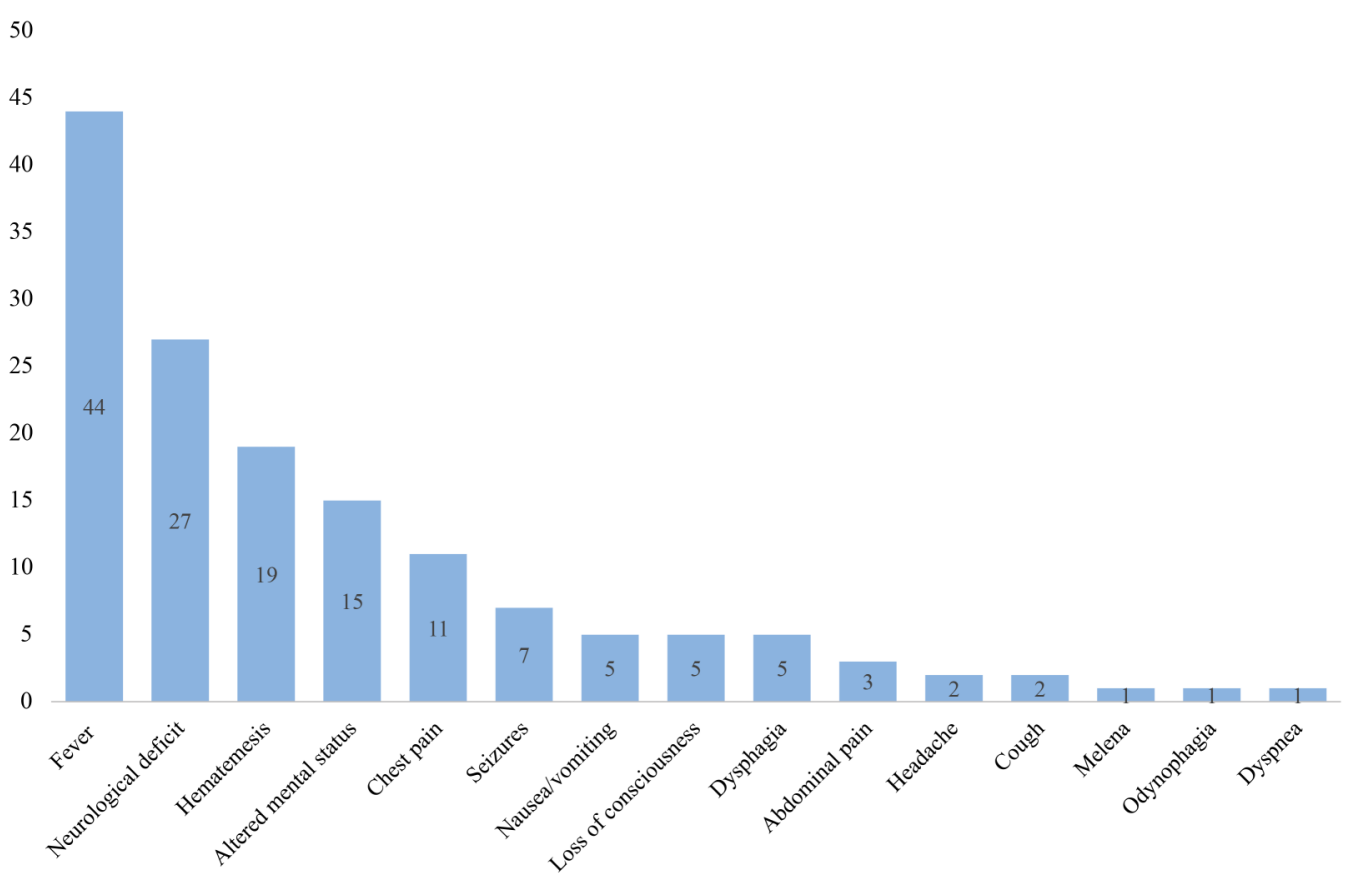

Figure 1 Frequency of symptoms at time of presentation. Neurological deficits include motor and language impairment; altered mental status was also described as confusion.

explained by the fact that more men undergo RFA and that women are less likely get invasive treatment. ${ }^{46} \mathrm{AEF}$ typically presented $20 \pm 12$ days post-RFA, ranging from 2 to 60 days. Occasionally the patient might present repeatedly before a definitive diagnosis is made. ${ }^{11}$ The presenting symptoms can involve different organs and systems, including fever, neurological deficit, haematemesis, altered mental status, chest pain or a combination of these (figure 1). No association was found between onset of symptoms and mortality $(19 \pm 10$ vs $23 \pm 14$ days; $\mathrm{p}=0.355)$. Finsterer et $a t^{46}$ suggested that the latency between initial insult and the development of symptoms may depend on the fistula size, the treatment initially provided, and the number of additional complications. A high index of suspicion for this catastrophic complication is required for patients with a recent history of RFA in order to achieve a correct diagnosis and prompt management.

\section{Diagnostic procedures}

CT of the chest with intravenous contrast has shown to be the most useful diagnostic tool. ${ }^{22}{ }^{23}$ Other diagnostic techniques, such as CT of the head, can be useful. In this review, the most common findings were multifocal air embolism of the brain and pneumomediastinum. Several radiological features have been reported,
Figure 2 Diagnostic modalities on presentation to the emergency room (CT abd/pelvis, CT of the abdomen and pelvis with contrast; CT chest, CT of the chest with intravenous contrast; CT head, CT of the head without contrast; CCTA, computed cardiac tomographic angiograph; . MRI brain, MRI of the brain; TEE, transesophageal echocardiography; TTE, transthoracic echocardiography).

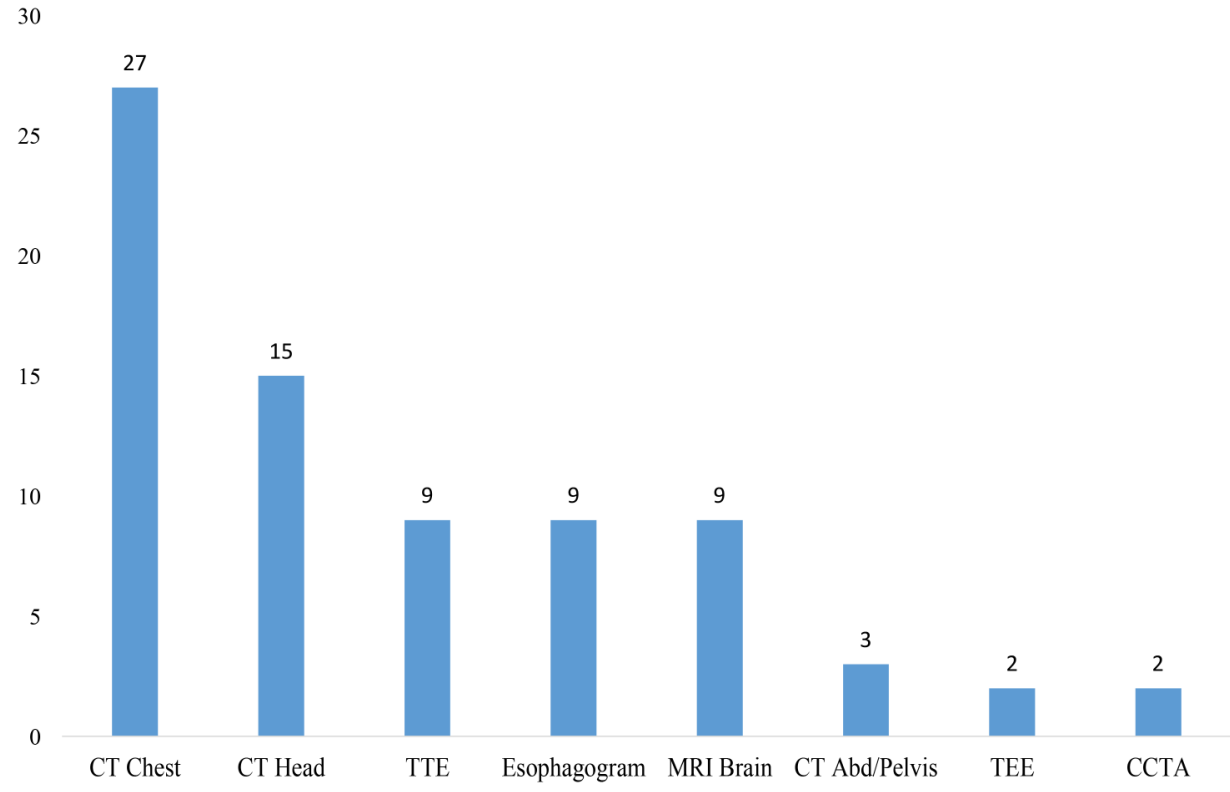


including pericardial effusion and the obvious communication between the atrium and the pericardium or the esophagus. ${ }^{12} 51$ TEE and/or esophagogastroduodenoscopy (EGD) are precluded at any suspicion of AEF. Air insufflation during TEE or EGD may lead to massive embolisation, resulting in severe neurological injury and death. ${ }^{4} 578 \quad 11-13151821242628303235363844$ If systemic bacterial endocarditis is suspected, avoiding TEE could prove lifesaving. ${ }^{13}$

\section{Anatomical contributing factors}

Unfortunately, despite efforts to determine how this complication occurs, there is little understanding in the pathogenesis of AEF.

Gillinov et $a \tilde{l}^{2}$ considered that body size, when extremely small, may contribute to perforation, assuming thinner patients are more likely to have a thin left posterior atrial wall. ${ }^{14}$ Sonmez et at $t^{4}$ suggested that a thin atrial wall could also result from atrial enlargement (>60 $\mathrm{mm}$ in diameter). Paradoxically, others like Lemola et $a \tilde{l}^{33}$ proposed that a small LA might be at higher risk for fistula formation because the esophagus may occupy a larger relative area of the posterior LA, where much of the ablation is performed.

The absence of a fat layer between the esophagus and atrium may identify patients at higher risk of esophageal injury ${ }^{53}$; the distance is often $<5 \mathrm{~mm}$ from the esophagus to the endocardial layer of the atrium. ${ }^{14}$ This hypothesis is supported by a cadaver study that showed marked individual variation of thickness of the posterior left atrial wall and the fibrofatty layer between the atrium and the esophagus. ${ }^{9} 54$

\section{Procedural contributing factors}

The incidence of AEF following percutaneous ablation has ranged from $0.01 \%$ to $0.2 \%$, and is as high as $1-1.5 \%$ for patients undergoing surgical ablations. $^{2} 56124555-57$ This report includes 12 surgical and 41 percutaneous cases of AEF after RFA for AF. The higher number of percutaneous cases could be explained by the increased use of this therapeutic modality. However, given the overall small numbers of cases reported in the literature, it is not known whether the incidence of AEF differs when done surgically or percutaneously. ${ }^{12}$

The accountability of an individual operator technique is inevitably implicit. In early cases, TEE was used as a standard imaging aid during ablation procedures. When the probe is left during the procedure, it mechanically displaces the esophagus towards the ablation catheter, increasing the heat transfer to the esophageal mucosa. ${ }^{58}$ Attempts to reduce temperature have been achieved with the use of cryoballoon technology for pulmonary vein isolation; however, despite this, AEF may still occur. ${ }^{29}$

Given that direct thermal injury may account for the development of AEF, it seems critical to determine the role of intraoesophageal temperatures during ablation procedures. There are, however, case reports of $\mathrm{AEF}$ without significant change in esophageal temperature. $^{5} 91516 \quad 18 \quad 37$ Changes in the esophageal mucosa consistent with thermal injury are commonly seen in about $47 \%$ cases, while ulceration may occur in $14-18 \%$ cases. ${ }^{59}{ }^{60}$ One case series reporting the development of fistula in four patients showed no statistically significant difference when comparing AEF to AEF-free cases, although mean maximum temperature and total energy appeared slightly higher in the esophageal injury group. ${ }^{5}$ The risk for developing AEF is augmented by magnitude and duration of local heating, which is related to catheter tip size, contact pressure, catheter orientation, the number of linear lesions sets in the posterior wall, as well as the power output and duration associated with each lesion. Furthermore, general anaesthesia during catheter ablation may increase the risk of esophageal wall injury given the alteration in the physiological motility of the esophagus. ${ }^{61}$

\section{Treatment}

Surgical intervention has been considered the standard of care, though isolated cases of successful conservative management have been reported. ${ }^{21}$ Only two of five cases treated with esophageal stenting survived after the procedure. $^{89182127}$ Nevertheless, pericardioesophageal fistulas have been reported to be successfully managed with esophageal stenting when detected early (at days 26, 9 and 18 after the ablation procedure in the cases reported). ${ }^{51}$ Broad-spectrum antibiotics should be started concomitantly. Complications, such as stent dislocation, embolic and/or septic events, and stenosis may follow; therefore, patients should be closely followed.

Surgical repairs require cardiopulmonary bypass in order to first excise and replace the necrotic tissue in an intracardiac fashion. ${ }^{5}$ This method allows abolition of gaseous and bacteremic contamination within a locally aseptic, blood-rich, and tissue-friendly environment. ${ }^{34}$

Esophageal resections constitute the second step of treatment. Stenting is not considered as first-line therapy as yet, but has been reported as a temporary measure in bridging to definitive surgical intervention and lately as an alternative management therapy when patients are unable to undergo surgery. ${ }^{51}$ Only one case reported successful stenting as an end point. ${ }^{933}$ Novel alternatives have been proposed such as cervical esophageal ligation and decompression. ${ }^{26}$

Conservative management of esophageal perforation remains controversial with mortality rates ranging from $20 \%$ to $45 \%{ }^{9}$ According to the included cases (table 1), patients who did not receive a primary esophageal repair were more likely to have a deadly outcome $(34 \%$ with surgical treatment vs $83 \%$ with conservative treatment; $p<0.05$ ). This may be owing to the critical status at presentation of this group of patients. All the patients with suspected AEF should be transferred to a hospital equipped with cardiothoracic surgery facilities.

\section{Outcome}

AEF has reportedly been associated with a mortality rate of $40-80 \% .{ }^{12}{ }^{45}$ In this review, we found no difference in mortality rate between patients who underwent surgical 
RFA when compared with percutaneous RFA (58\% vs $56 \% ; \mathrm{p}=0.579$ ). Prior reports evidence lower mortality rates in the surgical RFA group, suggesting that there is a higher awareness of a complication when the procedure is done surgically. ${ }^{47}$ The complications following AEF, if survival is achieved, include multiple septicemias and even Guillain-Barré syndrome. ${ }^{12}$ No instances of spontaneous resolution have been reported.

\section{Procedural suggestions and prevention}

Technology advances now allow detailed mapping of the cardiac-esophageal interface by preprocedural and/or intraprocedural imaging; and energy delivery may be guided by intracardiac echocardiography. ${ }^{25}$ Nonetheless, cases of esophageal perforation, seen when using robotic mapping methods, have been reported.$^{61}$

Patwardhan et a ${ }^{62}$ hinted that the bipolar mode of RF would be safer than the unipolar mode, since it-in theory - prevents energy dispersion and thus the formation of AEF. ${ }^{37}$ Lower power setting and shorter lesion durations in the posterior aspect of the LA have been suggested as possible ways to avoid this complication. However, power has been shown to be a weak predictor of intraesophageal temperature during ablation and even power settings $<10 \mathrm{~W}$ may increase luminal temperatures in the esophagus and cause $\mathrm{AEF}^{63}$ Intraoperative esophageal temperature monitoring has emerged as a method that allows the operator to stop the delivery of energy when increasing esophageal temperatures are detected. ${ }^{19}{ }^{64}$ Since the esophageal temperature can continue to increase for few seconds after discontinuation of energy delivery, immediate discontinuation of radiofrequency application has been suggested if esophageal temperatures increase rapidly or reach more than an absolute temperature of $39^{\circ} \mathrm{C} .{ }^{9}$

RFA uses a point-by-point system that entails absorptive heating and induction of thermal necrosis as mechanisms of action. Using an open-irrigated catheter lowers the energy output when compared to a standard $8 \mathrm{~mm}$ tip catheter and was found to decrease the rate of esophageal ulceration; however, all the ablation catheters still carry the risk of AEF. ${ }^{65}$

Newer imaging techniques, such as combining the use of barium sulfate paste during CT or gadolinium diglutamate during MRI, are currently used to visualise the anatomical relationship between esophagus, pulmonary veins and LA position wall. The integration of these imaging modalities and current 3-D mapping systems (CARTO-3 or EnSite Velocity) provides a visualisation tool to understand the complex anatomy, and can play an important role in prevention of esophageal injury. Piorkowski et $a{ }^{66}$ reported a high accuracy in visualising the true anatomic relationship of the esophagus and LA by preprocedural CT scan, and its intraprocedural position by using electro-anatomic mapping systems.

\section{CONCLUSION}

AEF following ablation procedures for $\mathrm{AF}$ is a serious complication with high mortality rates. It is critical to be aware of this complication in the outcome sequence of catheter ablation. Presenting symptoms most often include a triad of fever, neurological deficit and/or haematemesis. Prompt diagnostic work-up should include a CT-chest. TEE is contraindicated even when endocarditis is suspected. Survival depends on rapid diagnosis and intervention. When untreated, the outcome is more often fatal. Thorough patient education regarding signs and symptoms of esophageal injury upon discharge is warranted.

Contributors PC, FHM, ACD, EFA, TS, DG, CDB and SD were responsible for conception and design of study; analysis and interpretation of data and drafting of the manuscript; final approval of the manuscript submitted and agreement to be accountable for all aspects of the work.

Competing interests FHM Ad hoc consultant for the following organisations: Daiichi Sankyo, Pfizer, Takeda, Abbott, Servier, Medtronic, Ipca Laboratories Ltd.

Provenance and peer review Not commissioned; externally peer reviewed.

Open Access This is an Open Access article distributed in accordance with the Creative Commons Attribution Non Commercial (CC BY-NC 4.0) license, which permits others to distribute, remix, adapt, build upon this work noncommercially, and license their derivative works on different terms, provided the original work is properly cited and the use is non-commercial. See: http:// creativecommons.org/licenses/by-nc/4.0/

\section{REFERENCES}

1. Fisher JD, Spinelli MA, Mookherjee D, et al. Atrial fibrillation ablation: reaching the mainstream. Pacing Clin Electrophysiol 2006;29:523-37.

2. Mohr FW, Fabricius AM, Falk V, et al. Curative treatment of atrial fibrillation with intraoperative radiofrequency ablation: short-term and midterm results. J Thorac Cardiovasc Surg 2002;123:919-27.

3. Moher D, Liberati A, Tetzlaff J, et al. Preferred reporting items for systematic reviews and meta-analyses: the PRISMA statement. Int J Surg 2010;8:336-41.

4. Sonmez B, Demirsoy E, Yagan N, et al. A fatal complication due to radiofrequency ablation for atrial fibrillation: atrio-esophageal fistula. Ann Thorac Surg 2003;76:281-3.

5. Doll N, Borger MA, Fabricius A, et al. Esophageal perforation during left atrial radiofrequency ablation: is the risk too high? J Thorac Cardiovasc Surg 2003;125:836-42.

6. Pappone C, Oral H, Santinelli V, et al. Atrio-esophageal fistula as a complication of percutaneous transcatheter ablation of atrial fibrillation. Circulation 2004;109:2724-6.

7. Scanavacca MI, D'Avila A, Parga J, et al. Left atrial-esophageal fistula following radiofrequency catheter ablation of atrial fibrillation. J Cardiovasc Electrophysiol 2004;15:960-2.

8. Zirlik A, Nordt TK. Massive air embolism after Maze. Heart 2005;91:736.

9. Bunch TJ, Nelson J, Foley T, et al. Temporary esophageal stenting allows healing of esophageal perforations following atrial fibrillation ablation procedures. J Cardiovasc Electrophysiol 2006;17:435-9.

10. Schley P, Gulker H, Horlitz M. Atrio-oesophageal fistula following circumferential pulmonary vein ablation: verification of diagnosis with multislice computed tomography. Europace 2006;8:189-90.

11. Cummings JE, Schweikert RA, Saliba WI, et al. Brief communication: atrial-esophageal fistulas after radiofrequency ablation. Ann Intern Med 2006;144:572-4.

12. Dagres $\mathrm{N}$, Kottkamp H, Piorkowski $\mathrm{C}$, et al. Rapid detection and successful treatment of esophageal perforation after radiofrequency ablation of atrial fibrillation: lessons from five cases. J Cardiovasc Electrophysiol 2006;17:1213-15.

13. Preis O, Digumarthy SR, Wright CD, et al. Atrioesophageal fistula after catheter pulmonary venous ablation for atrial fibrillation: imaging features. J Thorac Imaging 2007;22:283-5.

14. Malamis AP, Kirshenbaum KJ, Nadimpalli S. CT radiographic findings: atrio-esophageal fistula after transcatheter percutaneous ablation of atrial fibrillation. J Thorac Imaging 2007;22:188-91. 
15. D'Avila A, Ptaszek LM, Yu PB, et al. Images in cardiovascular medicine. Left atrial-esophageal fistula after pulmonary vein isolation: a cautionary tale. Circulation 2007;115:e432-3.

16. Borchert B, Lawrenz T, Hansky B, et al. Lethal atrioesophageal fistula after pulmonary vein isolation using high-intensity focused ultrasound (HIFU). Heart Rhythm 2008;5:145-8.

17. Ouchikhe A, Maindivide J, Le Bivic JL, et al. Atrio-oesophageal fistula after radiofrequency ablation: predominant neurological symptoms. Ann Fr Anesth Reanim 2008;27:499-501.

18. Hazell W, Heaven D, Kazemi A, et al. Atrio-oesophageal fistula: an emergent complication of radiofrequency ablation. Emerg Med Australas 2009;21:329-32.

19. Vijayaraman P, Netrebko P, Geyfman V, et al. Esophageal fistula formation despite esophageal monitoring and low-power radiofrequency catheter ablation for atrial fibrillation. Circ Arrhythm Electrophysiol 2009;2:e31-3.

20. Baker MJ, Panchal PC, Allenby PA. Life-threatening GI hemorrhage caused by atrioesophageal fistula: a rare complication after catheter ablation for atrial fibrillation. Gastrointest Endosc 2010;72:887-9.

21. Cazavet A, Muscari F, Marachet MA, et al. Successful surgery for atrioesophageal fistula caused by transcatheter ablation of atrial fibrillation. J Thorac Cardiovasc Surg 2010;140:e43-5.

22. Gilcrease GW, Stein JB. A delayed case of fatal atrioesophageal fistula following radiofrequency ablation for atrial fibrillation. J Cardiovasc Electrophysiol 2010;21:708-11.

23. Khandhar S, Nitzschke S, Ad N. Left atrioesophageal fistula following catheter ablation for atrial fibrillation: off-bypass, primary repair using an extrapericardial approach. J Thorac Cardiovasc Surg 2010;139:507-9.

24. Siegel MO, Parenti DM, Simon GL. Atrial-esophageal fistula after atrial radiofrequency catheter ablation. Clin Infect Dis 2010;51: 73-6.

25. Grubina R, Cha YM, Bell MR, et al. Pneumopericardium following radiofrequency ablation for atrial fibrillation: insights into the natural history of atrial esophageal fistula formation. $J$ Cardiovasc Electrophysiol 2010;21:1046-9.

26. St Julien J, Putnam JB Jr, Nesbitt JC, et al. Successful treatment of atrioesophageal fistula by cervical esophageal ligation and decompression. Ann Thorac Surg 2011;91:e85-6.

27. Zellerhoff S, Lenze F, Schulz R, et al. Fatal course of esophageal stenting of an atrioesophageal fistula after atrial fibrillation ablation Heart Rhythm 2011;8:624-6.

28. Purerfellner $\mathrm{H}$, Stöllberger $\mathrm{C}$, Finsterer J. Meningo-encephalitis as initial manifestation of a fatal atrio-oesophageal fistula after atrial fibrillation ablation. Acta Cardiol 2011;66:555-7.

29. Stockigt F, Schrickel JW, Andrie R, et al. Atrioesophageal fistula after cryoballoon pulmonary vein isolation. $J$ Cardiovasc Electrophysiol 2012;23:1254-7.

30. Tancevski I, Hintringer F, Stuehlinger M, et al. Atrioesophageal fistula after percutaneous transcatheter ablation of atrial fibrillation. Circulation 2012;125:966.

31. Haggerty KA, George TJ, Arnaoutakis GJ, et al. Successful repair of an atrioesophageal fistula after catheter ablation for atrial fibrillation. Ann Thorac Surg 2012;93:313-15.

32. Kanth P, Fang J. Cerebral air embolism: a complication of a bleeding atrioesophageal fistula. Clin Gastroenterol Hepatol 2012; 10:A22.

33. Ben-David K, Rosenthal M, Chauhan SS. A novel strategy for the management of acute hemorrhage from an atrio-esophageal fistula after atrial ablation. Am Surg 2012;78:E286-7.

34. Hartman AR, Glassman L, Katz S, et al. Surgical repair of a left atrial-esophageal fistula after radiofrequency catheter ablation for atrial fibrillation. Ann Thorac Surg 2012;94:e91-3.

35. Zini A, Carpeggiani P, Pinelli G, et al. Brain air embolism secondary to atrial-esophageal fistula. Arch Neurol 2012;69:785.

36. Rivera GA, David IB, Anand RG. Successful atrioesophageal fistula repair after atrial fibrillation ablation. J Am Coll Cardiol 2013;61: 1204.

37. Tan C, Coffey A. Atrioesophageal fistula after surgical unipolar radiofrequency atrial ablation for atrial fibrillation. Ann Thorac Surg 2013;95:e61-2.

38. Shim HB, Kim C, Kim HK, et al. Successful management of atrio-esophageal fistula after cardiac radiofrequency catheter ablation. Korean J Thorac Cardiovasc Surg 2013;46:142-5.

39. Neven K, Schmidt B, Metzner A, et al. Fatal end of a safety algorithm for pulmonary vein isolation with use of high-intensity focused ultrasound. Circ Arrhythm Electrophysiol 2010;3:260-5.

40. Dixit S, Gerstenfeld EP, Ratcliffe SJ, et al. Single procedure efficacy of isolating all versus arrhythmogenic pulmonary veins on long-term control of atrial fibrillation: a prospective randomized study. Heart Rhythm 2008;5:174-81.
41. Aghasadeghi $\mathrm{K}$, Aslani A. Aquarium sign in the left atrium. Cardiology 2007:107:411.

42. Kneeland PP, Fang MC. Trends in catheter ablation for atrial fibrillation in the United States. J Hosp Med 2009:4:E1-5.

43. Pappone C, Santinelli V. Atrial fibrillation ablation: state of the art. Am J Cardiol 2005;96:59L-64L.

44. Sonmez B, Demirsoy E, Yilmaz O. Atrioesophageal fistula: is it an unavoidable complication of radiofrequency ablation? $J$ Thorac Cardiovasc Surg 2003;126:1662-3; author reply 63.

45. Ghia KK, Chugh A, Good E, et al. A nationwide survey on the prevalence of atrioesophageal fistula after left atrial radiofrequency catheter ablation. J Interv Card Electrophysiol 2009;24:33-6.

46. Finsterer J, Stöllberger C, Pulgram T. Neurological manifestations of atrio-esophageal fistulas from left atrial ablation. Eur $\mathrm{J}$ Neurol 2011:18:1212-19.

47. Stöllberger C, Pulgram T, Finsterer J. Neurological consequences of atrioesophageal fistula after radiofrequency ablation in atrial fibrillation. Arch Neurol 2009;66:884-7.

48. Nair GM, Nery PB, Redpath CJ, et al. Atrioesophageal fistula in the era of atrial fibrillation ablation: a review. Can J Cardiol 2014:30:388-95.

49. Singh SM, d'Avila A, Singh SK, et al. Clinical outcomes after repair of left atrial esophageal fistulas occurring after atrial fibrillation ablation procedures. Heart Rhythm 2013;10:1591-7.

50. Gerstenfeld EP, Callans D, Dixit S, et al. Characteristics of patients undergoing atrial fibrillation ablation: trends over a seven-year period 1999-2005. J Cardiovasc Electrophysiol 2007;18:23-8.

51. Eitel C, Rolf S, Zachaus M, et al. Successful nonsurgical treatment of esophagopericardial fistulas after atrial fibrillation catheter ablation: a case series. Circ Arrhythm Electrophysiol 2013;6:675-81.

52. Gillinov AM, Pettersson G, Rice TW. Esophageal injury during radiofrequency ablation for atrial fibrillation. $J$ Thorac Cardiovasc Surg 2001;122:1239-40.

53. Lemola K, Sneider M, Desjardins B, et al. Computed tomographic analysis of the anatomy of the left atrium and the esophagus: implications for left atrial catheter ablation. Circulation 2004:110:3655-60.

54. Sanchez-Quintana D, Cabrera JA, Climent V, et al. Anatomic relations between the esophagus and left atrium and relevance for ablation of atrial fibrillation. Circulation 2005;112:1400-5.

55. Dagres N, Hindricks G, Kottkamp H, et al. Complications of atrial fibrillation ablation in a high-volume center in 1,000 procedures: still cause for concern? J Cardiovasc Electrophysiol 2009;20:1014-19.

56. Cappato R, Calkins H, Chen SA, et al. Prevalence and causes of fatal outcome in catheter ablation of atrial fibrillation. J Am Coll Cardiol 2009;53:1798-803.

57. Ren JF, Lin D, Marchlinski FE, et al. Esophageal imaging and strategies for avoiding injury during left atrial ablation for atrial fibrillation. Heart Rhythm 2006;3:1156-61.

58. Bunch TJ, Day JD. Examining the risks and benefits of transesophageal echocardiogram imaging during catheter ablation for atrial fibrillation. Circ Arrhythm Electrophysiol 2012;5:621-3.

59. Halm U, Gaspar T, Zachaus M, et al. Thermal esophageal lesions after radiofrequency catheter ablation of left atrial arrhythmias. Am J Gastroenterol 2010;105:551-6.

60. Schmidt M, Nolker G, Marschang $\mathrm{H}$, et al. Incidence of oesophageal wall injury post-pulmonary vein antrum isolation for treatment of patients with atrial fibrillation. Europace 2008;10:205-9.

61. Shalaby A, Refaat M, Sebastien G, et al. Conservative management of pericardial-esophageal fistula complicating robotic atrial fibrillation ablation. Heart Rhythm 2011:8:905-8.

62. Patwardhan AM, Dave HH, Tamhane AA, et al. Intraoperative radiofrequency microbipolar coagulation to replace incisions of maze III procedure for correcting atrial fibrillation in patients with rheumatic valvular disease. Eur J Cardiothorac Surg 1997;12:627-33.

63. Cummings JE, Schweikert RA, Saliba WI, et al. Assessment of temperature, proximity, and course of the esophagus during radiofrequency ablation within the left atrium. Circulation 2005;112:459-64

64. Redfearn DP, Trim GM, Skanes AC, et al. Esophageal temperature monitoring during radiofrequency ablation of atrial fibrillation. J Cardiovasc Electrophysiol 2005;16:589-93.

65. Martinek M, Bencsik G, Aichinger J, et al. Esophageal damage during radiofrequency ablation of atrial fibrillation: impact of energy settings, lesion sets, and esophageal visualization. J Cardiovasc Electrophysiol 2009;20:726-33

66. Piorkowski C, Hindricks G, Schreiber D, et al. Electroanatomic reconstruction of the left atrium, pulmonary veins, and esophagus compared with the "true anatomy" on multislice computed tomography in patients undergoing catheter ablation of atrial fibrillation. Heart Rhythm 2006;3:317-27. 